\title{
Chronic Hemolytic Anemia due to Cold Agglutinins: the Mechanism of Resistance of Red Cells to $C^{\prime}$ Hemolysis by Cold Agglutinins *
}

\author{
Robert S. Evans, Elizabeth Turner, and Margaret Bingham \\ (From the Medical Service of the Veterans Administration Hospital and the Department of \\ Medicine of the University of Washington School of Medicine, \\ Seattle, Washington)
}

\begin{abstract}
The red cells of patients with chronic hemolytic anemia due to cold agglutinins are agglutinated by antiglobulin serum in a nongamma reaction due to the coating of $\beta$-globulins, $C^{\prime} 4$ and $C^{\prime} 3$. The red cells of such patients are abnormally resistant to $C^{\prime}$ hemolysis by cold agglutinin.

Normal red cells can be made equally resistant to $C^{\prime}$ hemolysis by incubation with cold agglutinin and normal serum at temperatures which allow transient reactions between the red cells and cold agglutinins. The development of resistance to $C^{\prime}$ hemolysis was related to increasing susceptibility to agglutination in anti- $\beta_{1 \mathrm{c}^{-}}$and anti- $\beta_{1 \mathrm{e}^{-}}$-sera and by increasing uptake of ${ }^{131} \mathrm{I}$ activity from labeled anti- $\beta$-globulin serum containing antibodies for both globulins. There was decrease in the adsorption of ${ }^{131}$ I-labeled cold agglutinin during the development of resistance to $\mathrm{C}^{\prime}$ hemolysis and reduced susceptibility to agglutination by cold agglutinins.

Since cold agglutinins have been demonstrated to dissociate from the red cell, leaving fractions of $\mathbf{C}^{\prime}$ globulin attached, it is postulated that repeated transient reactions produce the accumulation of incomplete $\mathbf{C}^{\prime}$ complexes. Steric hindrance by the adsorbed $\mathbf{C}^{\prime}$ complexes is probably responsible for the inhibition of the reaction with cold agglutinin. There is evidence that the adsorbed $\mathbf{C}^{\prime}$ complexes also interfere with the hemolytic action of $\mathbf{C}^{\prime}$ even when cold agglutinin has become reattached to the red cells.

The accumulation of $\mathbf{C}^{\prime}$ complexes by cold agglutinins appears to be the most important factor in the abnormal resistance to $\mathbf{C}^{\prime}$ hemolysis exhibited by the patient's red cells. Other factors, such as the heterogeneity within a population of normal cells, appear to be of minor significance.
\end{abstract}

\section{Introduction}

The circulating red cells of patients with chronic hemolytic anemia caused by cold agglutinins are abnormal in two respects: they give a positive "nongamma" Coombs' test because of coating by $\mathrm{C}^{\prime}$ globulins, and they possess an unusual degree of

* Submitted for publication 18 April 1966; accepted 8 June 1967.

This study was supported by a grant-in-aid from the U. S. Public Health Project No. A-548, C16.

Address requests for reprints to Dr. Robert S. Evans, Chief, Medical Service, Veterans Administration Hospital, 4435 Beacon Avenue South, Seattle, Wash. 98108. resistance to $\mathrm{C}^{\prime}$ hemolysis by cold agglutinin (1, $2)$. The first abnormality can be explained by the observation that radioiodinated cold agglutinins dissociate from the red cell, leaving fractions of $\mathrm{C}^{\prime}$ globulin adherent to the cell surface $(3,4)$. Evidence is presented in this report that the second abnormality is due largely to the accumulation of $\mathrm{C}^{\prime}$ globulin by repeated reactions with cold agglutinin. Normal red cells develop resistance to $\mathrm{C}^{\prime}$ hemolysis equal to that of the patients' cells during incubation with cold agglutinin in the presence of $\mathrm{C}^{\prime}(5)$. We postulate that similar reactions falling short of hemolysis occur in vivo 
and that the accumulation of $\mathrm{C}^{\prime}$ globulins on the red cells interferes with further reaction with cold agglutinin and $\mathrm{C}^{\prime}$.

Serologic material. The sera of two patients, E.M., a $60 \mathrm{yr}$ old white male, and A.J., an $80 \mathrm{yr}$ old white female, with the syndrome of chronic hemolytic anemia and acrocyanosis were used in these studies. Both sera contained high titers of cold agglutinins of anti-I specificity. Normal group-O I-positive red cells were agglutinated at $5^{\circ} \mathrm{C}$ in dilutions varying from $1: 64,000$ to $1: 500,000$.

Red cells from a group-O I-positive donor were used in the studies related to the development of resistance to $C^{\prime}$ hemolysis by cold agglutinin and will be designated as normal red cells., Other normal red cells will be designated as to blood group and I or $\mathrm{i}$ type.

\section{Methods}

The methods used for observing $C^{\prime}$ hemolysis by cold agglutinin and for preparing and employing radioiodinated cold agglutinin have been previously described (2).

Preparation of anti-human globulin serum with activity for $\beta_{1 \mathrm{e}}$ - and $\beta_{1 \mathrm{e}}$-globulins. Serum with high titers of antibodies for human $\mathrm{C}^{\prime}$ globulins was obtained by the method of Gold and Lockyer (6). Activity for $\beta_{1 \mathrm{c}}$-globulin $\left(C^{\prime} 3\right)$ and $\beta_{10}$-globulin ( $\left.C^{\prime} 4\right)$ was demonstrated by precipitin bands in immunoelectrophoretic preparations $(7,8)$. This reagent will be referred to as anti- $\beta$-globulin serum. Less prominent bands for immunoglobins $G$ and $A$ were also present. Activity of these antibodies was inhibited by the addition of human immune globulin. ${ }^{1}$ Activity of anti- $\beta_{12}$-globulin antibodies was demonstrated by agglutination of red cells interacted with cold agglutinin and human serum that had been depleted of both $C^{\prime} 3$ and $C^{\prime} 2(9,10)$. Red cells reacted with $\mathrm{C}^{\prime} 1$ and $\mathrm{C}^{\prime} 4$ when washed three times at $37^{\circ} \mathrm{C}$ were agglutinated to a dilution of $1: 160$. Activity for $\beta_{10}$ was adsorbed by the $C^{\prime} 14$-coated cells. The adsorbed antiglobulin serum was retested for $\beta_{1 \mathrm{c}}$-activity by the agglutination of red cells remaining after partial hemolysis by cold agglutinin and whole serum. Such residual cells, when washed at $37^{\circ} \mathrm{C}$, were agglutinated by a 1:320 dilution of the adsorbed serum. This was interpreted as evidence of anti- $\boldsymbol{\beta}_{\mathrm{1c}}$-activity.

Additional antisera with activity for $\beta_{10}$ - or $\beta_{10}$-globulins prepared by injection of these individual fractions of $\beta$-globulins into rabbits were available and confirmed the activity of the anti- $\beta$-globulin serum described above. ${ }^{2}$

Preparations of ${ }^{121}$ I-labeled anti- $\beta$-globulin serum. The method of Horejsi and Smetana (11) was used to frac-

1 Antipolio immune globulin was used.

${ }^{2}$ Antisera for $\beta_{1 c^{-}}$and $\beta_{10}$-globulins were obtained through the courtesy of Dr. John Boyer, Cleveland. tionate the rabbit anti- $\beta$-globulin serum. The gamma globulin so obtained was dialyzed against $0.15 \mathrm{M} \mathrm{NaCl}$ and $0.20 \mathrm{M}$ borate buffer, $\mathrm{pH} 8.0$, overnight at $5^{\circ} \mathrm{C}$. The concentration of protein was determined by the biuret method. Trace amounts of ${ }^{131} \mathrm{I}$ were incorporated by the iodine monochloride technique (12). Precipitation of samples of the radioiodinated globulin by $10 \%$ trichloroacetic acid removed $92-96 \%$ of the ${ }^{131} \mathrm{I}$ activity.

The ${ }^{121}$ I-labeled anti- $\beta$-globulin serum agglutinated cells coated with $\mathrm{C}^{\prime}$ complex by the action of cold agglutinin and $\mathrm{R} 3$ serum to dilutions of $1: 640$. The adsorption of ${ }^{131}$ I activity by coated cells was compared to the uptake of radioactivity by normal cells. Nonspecific adsorption was reduced by the addition of bovine serum albumin to the anti- $\beta$-globulin serum (13). $0.02 \mathrm{ml}$ of packed red cells was suspended in a solution of $0.5 \mathrm{ml}$ of the radioiodinated anti- $\beta$-globulin serum, $0.2 \mathrm{ml}$ of $30 \% \mathrm{BSA}$, and $0.3 \mathrm{ml}$ of a 1:5 saline dilution of human immune globulin. The suspension was incubated for $15-20 \mathrm{~min}$ at $37^{\circ} \mathrm{C}$ before washing three times in 20 volumes of cold buffered saline. Microhematocrits were done in duplicate and the adsorbed radioactivity was expressed in counts per minute $/ 0.1 \mathrm{ml}$ of cells. The accuracy of microhematocrit determinations was confirmed by determinations of hemoglobin concentration after complete lysis. Determinations of osmotic fragility were also used to detect change in red cell volume during incubation. Since the radioactivity of anti- $\beta$-globulin preparations varied with intensity of labeling and decay of ${ }^{281} \mathrm{I}$, determinations done at different times were expressed as the uptake of radioactivity of cells coated with $C^{\prime}$ globulin divided by the background uptake of normal red cells.

Accumulation of $C^{\prime}$ globulins by normal human red cells. Red cells were incubated with cold agglutinin and human $C^{\prime}$ as follows: zymosan-adsorbed human serum (R3) or normal serum was mixed with the heat-inactivated patients' serum, the $\mathrm{pH}$ was adjusted to 7.3 , and normal red cells were added at $37^{\circ} \mathrm{C}$. The suspension was kept at $25^{\circ} \mathrm{C}$ until agglutination was observed and then warmed to $37^{\circ} \mathrm{C}$ until agglutinated cells had dispersed. The cooling and rewarming was repeated six times each hour. At the end of 1 and $2 \mathrm{hr}$, the cells were sedimented and the supernatant was replaced by a new mixture of the serum and cold agglutinin. Samples were removed at $0,1,2$, and $3 \mathrm{hr}$, washed three times at $37^{\circ} \mathrm{C}$, and tested for absorption of ${ }^{131}$ I-labeled anti- $\beta$ globulin serum and ${ }^{181} \mathrm{I}$-labeled cold agglutinin, as well as for susceptibility to $\mathrm{C}^{\prime}$ hemolysis. Hemolysis did not occur during the incubation of cells with cold agglutinin and R3 serum. Cells so treated were designated as having $C^{\prime} 142$ coating, although it is recognized that some $\beta_{1 \mathrm{c}}$-globulin was present in R3 serum and participated in the reaction as $C^{\prime} 3$ (14). Control suspensions of red cells in which EDTA was used to block the action of $\mathrm{C}^{\prime}$ during incubation were also prepared.

When normal serum was used in the preparation of $\mathrm{C}^{\prime}$-coated cells hemolysis occurred during incubation; this was most marked during the 1 st hr. The cells lost 
through $C^{\prime}$ hemolysis were measured by hematocrit and hemoglobin determinations before and after incubation. Cells treated in this way were designated as having $C^{\prime} 1423$ coating, indicating adherence of $\beta_{1 \mathrm{c}}$-globulin. Again, it is recognized that other fractions of the third component were also present (15). The behavior of the residual cells was compared with that of suspensions of control cells in which EDTA was used to block the action of $\mathrm{C}^{\prime}$ during incubation. In some experiments the temperature of incubation was alternated between $31^{\circ}$ and $37^{\circ} \mathrm{C}$, while in others the temperature of incubation was constant at $33^{\circ}$ or $37^{\circ} \mathrm{C}$.

Resistance to $C^{\prime}$ hemolysis. Normal red cells and red cells coated with $C^{\prime}$ complexes were tested for susceptibility to $C^{\prime}$ hemolysis by incubation in 4 volumes of the serum of E.M. or A.J. and in 16 volumes of normal serum. The $\mathrm{pH}$ of the serum was adjusted to 7.2 or 6.8 with $0.1 \mathrm{~N} \mathrm{HCl}$ before addition of the cells at $37^{\circ} \mathrm{C}$. The suspensions were incubated at $25^{\circ} \mathrm{C}$ for $30 \mathrm{~min}$. The cells were then sedimented and the supernatant hemoglobin compared with that produced by $100 \%$ hemolysis.

Complement titers were determined by the methods of Ecker, Pillemer, and Seifter and Pillemer and coworkers $(16,17)$.

Heterogeneity of normal red cells. $5 \mathrm{ml}$ of washed normal red cells was suspended in 40 volumes of a 1:20 dilution of the serum of E.M. (titer 1:500,000) in buffered isotonic saline. The suspension was left at $25^{\circ} \mathrm{C}$ for $1 \mathrm{hr}$ while the agglutinated cells sedimented. The supernatant suspension of cells was removed and the volume of these cells was computed from the microhematocrit. The agglutinated cells were sedimented three times at $37^{\circ} \mathrm{C}$, the supernatant removed, and the cells resuspended in $40 \mathrm{ml}$ of a $1: 80$ dilution of the serum of E.M. The suspension was again left for $1 \mathrm{hr}$ at $25^{\circ} \mathrm{C}$ and separated as before. The process of separating agglutinated from unagglutinated cells was repeated with $1: 320$, $1: 1280$, and $1: 5120$ dilutions of the serum.

$5 \mathrm{ml}$ of a suspension of normal cells from the same donor was also subjected to separation into agglutinated fractions by first suspending it in a 1:5120 dilution of the serum of E.M. and then incubating it at $25^{\circ} \mathrm{C}$ for $1 \mathrm{hr}$. In this instance the agglutinated cells were removed and their volume determined. The unagglutinated cells were sedimented at $37^{\circ} \mathrm{C}$, the supernatant was removed, and the cells were resuspended in the next higher concentration of cold agglutinins and again incubated at $25^{\circ} \mathrm{C}$.

Populations of cells removed in both experiments were washed three times at $37^{\circ} \mathrm{C}$ and $0.05 \mathrm{ml}$ of each was suspended in $0.5 \mathrm{ml}$ of the serum of E.M. and $1 \mathrm{ml}$ of normal serum at $\mathrm{pH}$ 7.0. After $1 \mathrm{hr}$ at $25^{\circ} \mathrm{C}$, the per cent hemolysis was determined by comparing the supernatant hemoglobin with $100 \%$ lysis.

Complement hemolysis of reticulocytes. Whole blood collected in EDTA was separated into a reticulocyte-rich and reticulocyte-poor layer by centrifugation at $800 \mathrm{rpm}$ for several 15-min periods following the method of Kan and Gardner (18). Reticulocyte counts were done with red cells from the top and bottom layers and uncentri-
TABLE I

Comparison of normal red cells with red cells of patients E.M. and A.J.

\begin{tabular}{|c|c|c|c|}
\hline Red cells & $\begin{array}{l}\text { Hemolysis } \\
\text { at } 25^{\circ} \mathrm{C} \text {, } \\
\text { pH } 7.2\end{array}$ & $\begin{array}{l}\text { 121 I-labeled } \\
\text { cold agglutinin } \\
\text { adsorption at } \\
25^{\circ} \mathrm{C}, \text { pH } 7.2\end{array}$ & $\begin{array}{l}\text { 121 I-labeled anti- } \\
\text { B-globulin activity } \\
\text { adsorption : patients' } \\
\text { cells/normal cells* }\end{array}$ \\
\hline $\begin{array}{l}\text { Normalf } \\
\text { E.M. } \\
\text { A.J. }\end{array}$ & $\begin{array}{l}\% \\
9-52 \\
0 \\
0\end{array}$ & $\begin{array}{l}\quad c p m / \min \\
6000-91,000 \\
3000 \\
2700\end{array}$ & $\begin{array}{l}1.0(0.95-1.05) \\
4.5-5.0 \\
4.0-4.7\end{array}$ \\
\hline
\end{tabular}

* Red cells from normal subjects did not vary more than $10 \%$ in the "nonspecific" uptake of ${ }^{181}$ I activity with any one preparation of labeled anti- $\beta$-globulin serum. The adsorption of anti- $\beta$-globulin activity by the patient's red cells is recorded as the multiple of the background adsorption by normal red cells.

$\ddagger$ Normal red cells from 200 adults were examined for susceptibility to $C^{\prime}$ hemolysis by cold agglutinin and uptake of 131 -labeled cold agglutinin.

fuged whole blood. $0.1 \mathrm{ml}$ of a $50 \%$ cell suspension from both layers and from uncentrifuged cells were added to a mixture of 10 volumes of serum of A.J. and 10 volumes of normal serum at $\mathrm{pH} 6.8$ and incubated for 30 $\min$ at $25^{\circ} \mathrm{C}$. The per cent hemolysis was determined and reticulocyte counts were done on the unhemolyzed cells of each suspension.

\section{Results}

Resistance of patients' cells to $C^{\prime}$ hemolysis by cold agglutinin. The red cells of E.M. and A.J. were resistant to $C^{\prime}$ hemolysis by the cold agglutinin and adsorbed less ${ }^{131}$ I-labeled cold agglutinin than normal cells. The adsorption of activity from ${ }^{131}$ I-labeled anti- $\beta$-globulin serum, based on multiple determinations during the course of the patients' chronic hemolytic anemia, was four to five times that adsorbed by normal red cells (Table I).

Development of resistance by normal red cells to $C^{\prime}$ hemolysis by cold agglutinin during incubation with cold agglutinin and $R 3$ serum. Three aliquots of normal group-O I-positive red cells were each suspended in a mixture of 2 volumes of patient's serum and 6 volumes of R3 serum. The results of observations made on cells removed at intervals during the $3 \mathrm{hr}$ of incubation appear in Fig. 1. The decrease in susceptibility to hemolysis when incubation was carried out at $\mathrm{pH}$ 7.2 and 6.8 is shown. The adsorption of ${ }^{131} \mathrm{I}$ labeled cold agglutinin by the red cells before and during incubation is presented as the percentage decrease during the $3 \mathrm{hr}$ period. The adsorption of ${ }^{131}$ I-labeled anti- $\beta$-globulin serum is expressed 
as the number of times the incubated cells exceeded the background adsorption by the normal cells. Agglutination of the cells in dilutions of anti- $\beta$-globulin sera is shown in Table II.

The above findings were typical of many other experiments with normal red cells, cold agglutinin, and R3 serum. Since hemolysis of the red cells during incubation did not occur, it is evident that the entire cell population acquired resistance to $C^{\prime}$ hemolysis. The reduced adsorption of ${ }^{131} \mathrm{I}$-labeled cold agglutinin in this and other experiments was reflected in some decrease in susceptibility of $\mathrm{C}^{\prime}$

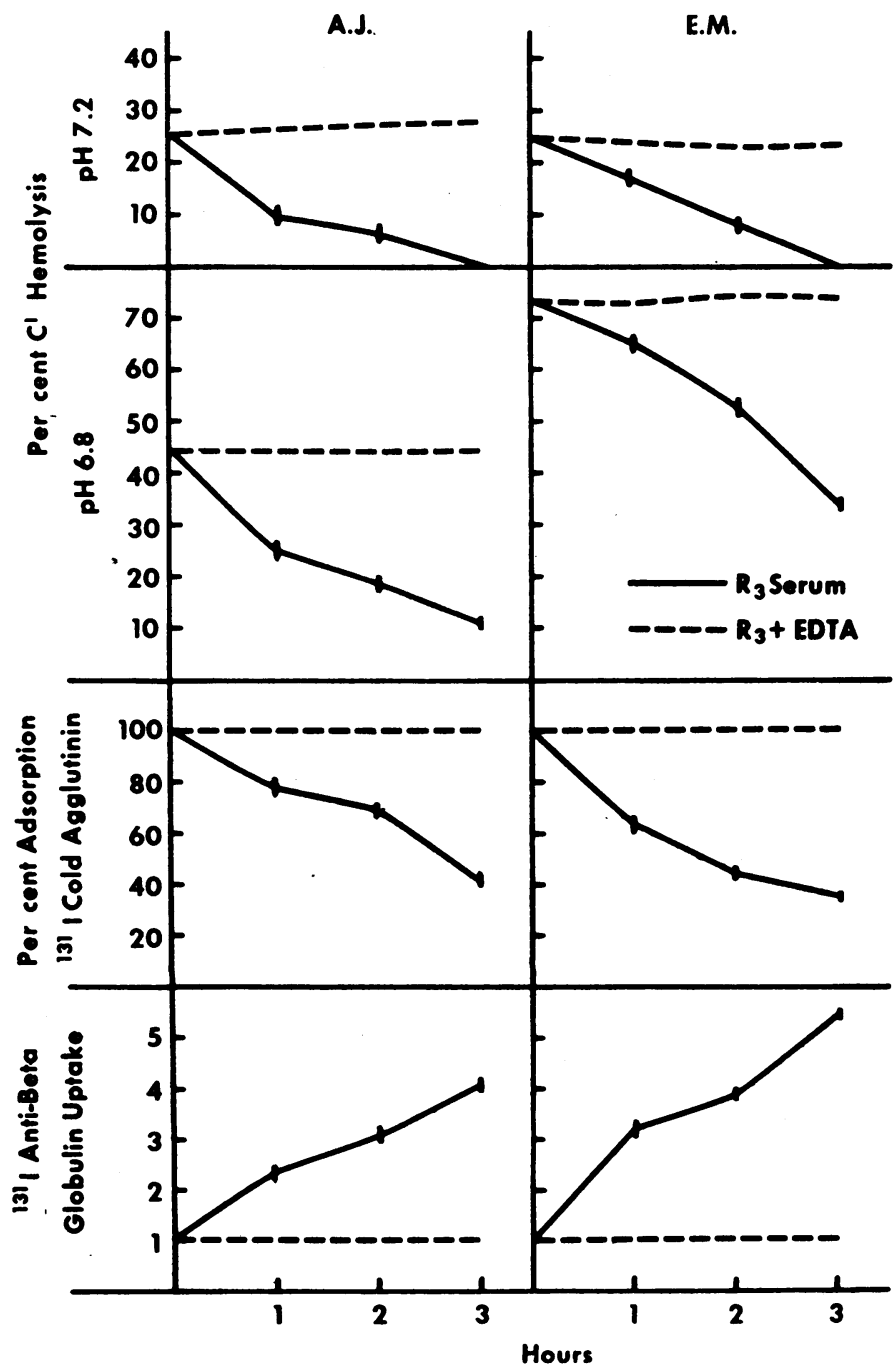

Fig. 1. The Development of Resistance to $\mathrm{C}^{\prime}$ Hemolysis by COLD AGGLUTININ DURING INCUBATION OF THREE ALIQUOTS OF NORMAL RED CELLS IN A MIXTURE OF R3 SERUM AND COLD AGGLUTININ AT TEMPERATURES ALTERNATING BETWEEN $25^{\circ}$ AND $37^{\circ} \mathrm{C}$. Vertical bars indicate the limits of variation in the determinations. Top two frames show the percentage of $\mathrm{C}^{\prime}$ hemolysis by cold agglutinins after each hour of incubation at $\mathrm{pH} 6.8$ and 7.2. Third frame down shows the per cent reduction in ${ }^{131}$ I-labeled cold agglutinin adsorption. In the lower frame, the adsorption of ${ }^{151} \mathrm{I}$-labeled anti- $\beta$-globulin activity by the $\mathrm{C}^{\prime}$ coated cells is expressed as the multiple of the background adsorption by normal cells. A suspension to which EDTA has been added to block the action of $\mathrm{C}^{\prime}$ served as a control. 
TABLE II

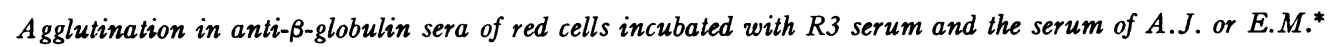

\begin{tabular}{|c|c|c|c|c|c|c|c|c|c|c|c|c|c|c|c|}
\hline \multirow{3}{*}{$\underset{\text { sera }}{\text { Antiglobulin }}$} & \multirow[b]{3}{*}{ Time } & \multicolumn{14}{|c|}{ Reciprocal of dilution of antisera } \\
\hline & & \multicolumn{7}{|c|}{ Serum of A.J. } & \multicolumn{7}{|c|}{ Serum of E.M. } \\
\hline & & 10 & 20 & 40 & 80 & 160 & 320 & 640 & 10 & 20 & 40 & 80 & 160 & 320 & 640 \\
\hline & $h r$ & & & & & & & & & & & & & & \\
\hline Anti- $\beta$-globulin & $\begin{array}{l}1 \\
2 \\
3\end{array}$ & $\begin{array}{l}3 \\
4 \\
4\end{array}$ & $\begin{array}{l}2 \\
4 \\
4\end{array}$ & $\begin{array}{l}1 \\
3 \\
3\end{array}$ & $\begin{array}{l}1 \\
2 \\
3\end{array}$ & $\begin{array}{l}0 \\
1 \\
2\end{array}$ & $\begin{array}{l}0 \\
0 \\
1\end{array}$ & $\begin{array}{l}0 \\
0 \\
0\end{array}$ & $\begin{array}{l}3 \\
4 \\
4\end{array}$ & $\begin{array}{l}2 \\
4 \\
4\end{array}$ & $\begin{array}{l}2 \\
3 \\
3\end{array}$ & $\begin{array}{l}1 \\
3 \\
3\end{array}$ & $\begin{array}{l}1 \\
1 \\
2\end{array}$ & $\begin{array}{l}0 \\
1 \\
1\end{array}$ & $\begin{array}{l}0 \\
0 \\
1\end{array}$ \\
\hline Anti- $\beta_{\text {le }}-$ globulin & $\begin{array}{l}1 \\
2 \\
3\end{array}$ & $\begin{array}{l}4 \\
4 \\
4\end{array}$ & $\begin{array}{l}4 \\
4 \\
4\end{array}$ & $\begin{array}{l}3 \\
3 \\
4\end{array}$ & $\begin{array}{l}2 \\
2 \\
4\end{array}$ & $\begin{array}{l}1 \\
2 \\
3\end{array}$ & $\begin{array}{l}0 \\
1 \\
2\end{array}$ & $\begin{array}{l}0 \\
0 \\
1\end{array}$ & $\begin{array}{l}4 \\
4 \\
4\end{array}$ & $\begin{array}{l}3 \\
4 \\
4\end{array}$ & $\begin{array}{l}3 \\
3 \\
4\end{array}$ & $\begin{array}{l}2 \\
2 \\
3\end{array}$ & $\begin{array}{l}1 \\
2 \\
2\end{array}$ & $\begin{array}{l}1 \\
1 \\
2\end{array}$ & $\begin{array}{l}0 \\
0 \\
1\end{array}$ \\
\hline Anti- $\beta_{\text {le }}$-globulin & $\begin{array}{l}1 \\
2 \\
3\end{array}$ & $\begin{array}{l}1 \\
3 \\
3\end{array}$ & $\begin{array}{l}1 \\
2 \\
3\end{array}$ & $\begin{array}{l}1 \\
1 \\
2\end{array}$ & $\begin{array}{l}0 \\
1 \\
2\end{array}$ & $\begin{array}{l}0 \\
0 \\
1\end{array}$ & $\begin{array}{l}0 \\
0 \\
0\end{array}$ & $\begin{array}{l}0 \\
0 \\
0\end{array}$ & $\begin{array}{l}2 \\
2 \\
4\end{array}$ & $\begin{array}{l}2 \\
2 \\
3\end{array}$ & $\begin{array}{l}2 \\
2 \\
2\end{array}$ & $\begin{array}{l}1 \\
2 \\
2\end{array}$ & $\begin{array}{l}1 \\
1 \\
2\end{array}$ & $\begin{array}{l}0 \\
1 \\
1\end{array}$ & $\begin{array}{l}0 \\
0 \\
0\end{array}$ \\
\hline
\end{tabular}

* Temperatures were alternated between 25 and $37^{\circ} \mathrm{C}$ six times per hour. At the end of each hour of incubation the serum mixture was replaced.

coated cells to agglutination in dilutions of cold agglutinin at $25^{\circ} \mathrm{C}$. Control cell suspensions incubated with EDTA remained unchanged to all agglutination reactions.

Comparison of zymosan-adsorbed serum $(R 3)$ and whole serum in the development of resistance by normal red cells to $C^{\prime}$ hemolysis by cold agglutinin. Normal red cells were suspended in one part of the patient's serum and three parts of R3 prepared from serum of a normal donor. A duplicate suspension was prepared with the whole serum of the same normal donor. The two suspensions were mixed at $37^{\circ} \mathrm{C}$ and then divided. One set of suspensions was incubated at temperatures alternating between $25^{\circ}$ and $37^{\circ} \mathrm{C}$. The duplicate suspensions were incubated at temperatures alternating between $31^{\circ}$ and $37^{\circ} \mathrm{C}$. The susceptibility of the red cells to $\mathrm{C}^{\prime}$ hemolysis by cold agglutinin, adsorption of ${ }^{131} \mathrm{I}$-labeled cold agglutinin and the adsorption of ${ }^{131} \mathrm{I}$-labeled anti- $\beta$-globulin serum are presented in Fig. 2.

In both experiments whole serum was more effective than R3 serum in producing inhibition of $\mathrm{C}^{\prime}$ hemolysis by cold agglutinins. Red cells reacted with whole serum adsorbed more ${ }^{131}$ I-labeled anti- $\beta$-globulin serum than cells incubated with R3 serum. Such cells also showed greater reduction in adsorption of ${ }^{131}$ I-labeled cold agglutinin, with the single exception of a $3 \mathrm{hr}$ determination with cells incubated with the cold agglutinin of E.M. The changes noted above were most marked with red cells incubated between $31^{\circ}$ and $37^{\circ} \mathrm{C}$ with the cold agglutinin of E.M. and between $25^{\circ}$ and $37^{\circ} \mathrm{C}$ with the cold agglutinin of A.J.

The amount of $\mathrm{C}^{\prime}$ hemolysis which occurred during each hour of incubation of the cells with cold agglutinin and whole serum is shown in Table III. There was relatively little hemolysis of normal cells during preparation of $C^{\prime} 1423$ cells with the serum of A.J. The serum of E.M. produced hemolysis of $70 \%$ of the normal cells during incubation at $31^{\circ}$ and $37^{\circ} \mathrm{C}$, the largest amount observed in any experiment. The surviving cells were completely resistant to $\mathrm{C}^{\prime}$ hemolysis by cold agglutinin at $\mathrm{pH} 6.8$.

The greater effectiveness of whole serum over R3 serum in producing the various changes depicted in Fig. 2 probably reflects the greater participation of $C^{\prime} 3$ ( $\beta_{1 \mathrm{c}}$-globulin) in the reaction. In addition, zymosan is believed to reduce the levels of all fractions of $C^{\prime}$ in the preparation of R3 serum (19).

TABLE III

$C^{\prime}$ hemolysis during incubation of normal $I$-positive red cells in A.J. serum and normal serum or E.M. serum and normal serum

\begin{tabular}{|c|c|c|c|c|}
\hline \multirow[b]{3}{*}{ Time } & \multicolumn{4}{|c|}{ Per cent hemolysis } \\
\hline & \multicolumn{2}{|c|}{ A.J. + normal sera } & \multicolumn{2}{|c|}{ E.M. + normal sera } \\
\hline & $25-37^{\circ} \mathrm{C}$ & $31-37^{\circ} \mathrm{C}$ & $25-37^{\circ} \mathrm{C}$ & $31-37^{\circ} \mathrm{C}$ \\
\hline \multicolumn{5}{|l|}{$h r$} \\
\hline $\begin{array}{l}1 \\
2 \\
3\end{array}$ & $\begin{array}{l}7.5 \\
4.0 \\
1.5\end{array}$ & $\begin{array}{l}3.5 \\
1.0 \\
0\end{array}$ & $\begin{array}{r}28.0 \\
15.5 \\
6.0\end{array}$ & $\begin{array}{r}43.5 \\
16.5 \\
9.5\end{array}$ \\
\hline
\end{tabular}




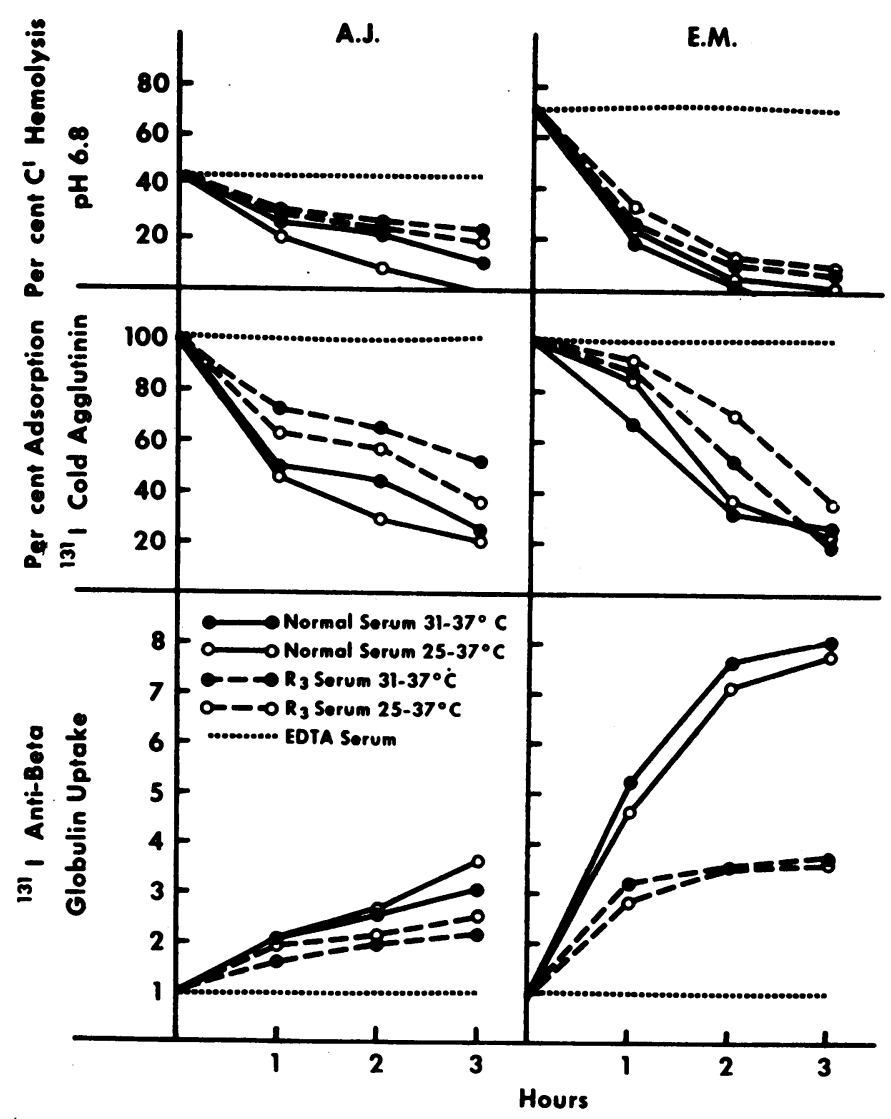

Fig. 2. The development of Resistance to $C^{\prime}$ hemolysis by COLD AGGLUTININ DURING INCUBATION OF NORMAL RED CELLS WITH COLD AGGLUTININ AND EITHER R3 SERUM OR NORMAL SERUM. Each suspension was divided in half, one set being incubated at temperatures alternating between $25^{\circ}$ and $37^{\circ} \mathrm{C}$ and the other at temperatures alternating between $31^{\circ}$ and $37^{\circ} \mathrm{C}$. Top frame shows the percentage of $\mathrm{C}^{\prime}$ hemolysis by cold agglutinin at $\mathrm{pH} 6.8$, middle frame the percentage reduction in ${ }^{131} \mathrm{I}$-labeled cold agglutinin adsorption, and bottom frame the adsorption of ${ }^{131} \mathrm{I}$-labeled anti- $\beta$ globulin serum recorded as the multiple of background adsorption by normal cells. A suspension with EDTA added to block the action of $\mathrm{C}^{\prime}$ served as a control.

Consumption of complement during the development of resistance to $C^{\prime}$ hemolysis by cold agglutinin. Normal red cells were suspended in an equal volume of the serum of the patients and 4 volumes of normal serum. The suspensions were divided into two aliquots. One was incubated at $33^{\circ} \mathrm{C}$ while the second was alternated between $31^{\circ}$ and $37^{\circ} \mathrm{C}$. Group-O I-negative cord cells were suspended and incubated in the same manner in control observations (20). At the end of each hour of incubation samples of the cells were tested for resistance to $C^{\prime}$ hemolysis and the adsorption of ${ }^{131} \mathrm{I}$-labeled anti- $\beta$-globulin serum. In addition, levels of $C^{\prime}$ in the serum mixture used for incubation were determined (Fig. 3 ).

As demonstrated in Fig. 3, the i-positive cord cells, deficient in I antigen, showed no increase in the uptake of ${ }^{131}$ I-labeled anti- $\beta$-globulin serum as a result of incubation with anti-I cold agglutinin and $C^{\prime}$ and continued to be nonagglutinable in anti- $\beta$-globulin serum. Decreases in levels of serum $C^{\prime}$ during incubation with these cells were slight and no greater than decreases noted when normal serum was kept at $37^{\circ} \mathrm{C}$ without red cells. 
A.J.

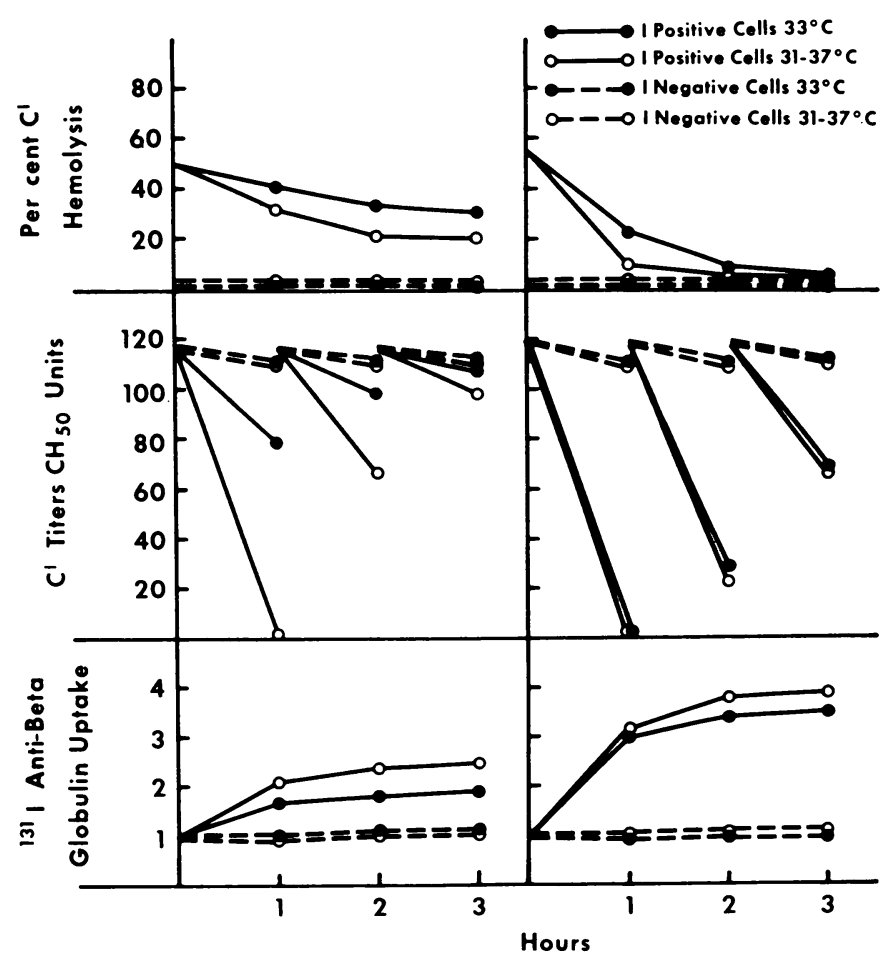

Fig. 3. The consumption of $\mathrm{C}^{\prime}$ from the incubating medium DCRING THE INCUBATION OF NORMAL I-POSITIVE RED CELLS WITH COLD AGGLUTININ AND NORMAL SERUM COMPARED WITH I-NEGATIVE CORD RED CELLS. The development of resistance of the I-positive cells to $\mathrm{C}^{\prime}$ hemolysis by cold agglutinin at $\mathrm{pH} 6.8$ is shown in the top frame and the adsorption of anti-B-globulin activity in the bottom frame.
The depletion of $\mathrm{C}^{\prime}$ from the serum in which I-positive cells were incubated was directly reflected in the increase in adsorption of ${ }^{131}$ I-labeled anti- $\beta$-globulin by these cells. The alternation in temperature between $31^{\circ}$ and $37^{\circ} \mathrm{C}$ was more effective in producing $\mathrm{C}^{\prime}$ fixation than incubation at a constant temperature of $33^{\circ} \mathrm{C}$. The adsorption of $\mathrm{C}^{\prime}$ by the I-positive red cells is also re-

TABLE IV

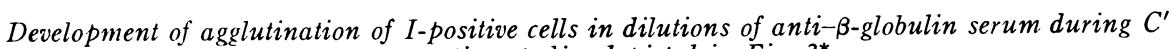
consumption studies depicted in Fig. $3^{*}$

\begin{tabular}{|c|c|c|c|c|c|c|c|c|c|c|c|c|c|c|c|}
\hline \multirow{3}{*}{$\underset{\text { ture }}{\text { Tempera- }}$} & \multirow[b]{3}{*}{ Time } & \multicolumn{14}{|c|}{ Reciprocal of dilution of antisera } \\
\hline & & \multicolumn{7}{|c|}{ Serum of A.J. } & \multicolumn{7}{|c|}{ Serum of E.M. } \\
\hline & & 5 & 10 & 20 & 40 & 80 & 160 & 320 & 5 & 10 & 20 & 40 & 80 & 160 & 320 \\
\hline & $h r$ & & & & & & & & & & & & & & \\
\hline \multirow[t]{3}{*}{$33^{\circ} \mathrm{C}$} & 1 & 1 & 1 & 0 & 0 & 0 & 0 & 0 & 4 & 3 & 2 & 1 & 1 & 0 & 0 \\
\hline & 2 & 1 & 1 & 1 & 0 & 0 & 0 & 0 & 4 & 3 & 3 & 2 & 1 & 1 & 0 \\
\hline & 3 & 1 & 2 & 1 & 1 & 1 & 0 & 0 & 4 & 3 & 3 & 2 & 1 & 1 & 0 \\
\hline \multirow[t]{3}{*}{$31^{\circ}-37^{\circ} \mathrm{C}$} & 1 & 2 & 2 & 1 & 1 & 0 & 0 & 0 & 4 & 3 & 3 & 1 & 1 & 0 & 0 \\
\hline & 2 & 3 & 2 & 2 & 1 & 1 & 0 & 0 & 4 & 3 & 3 & 2 & 1 & 1 & 0 \\
\hline & 3 & 3 & 3 & 3 & 2 & 1 & 1 & 0 & 4 & 4 & 3 & 2 & 2 & 1 & 1 \\
\hline
\end{tabular}

* The I-positive cord cells were not agglutinated by anti- $\beta$-globulin serum before or after incubation. 


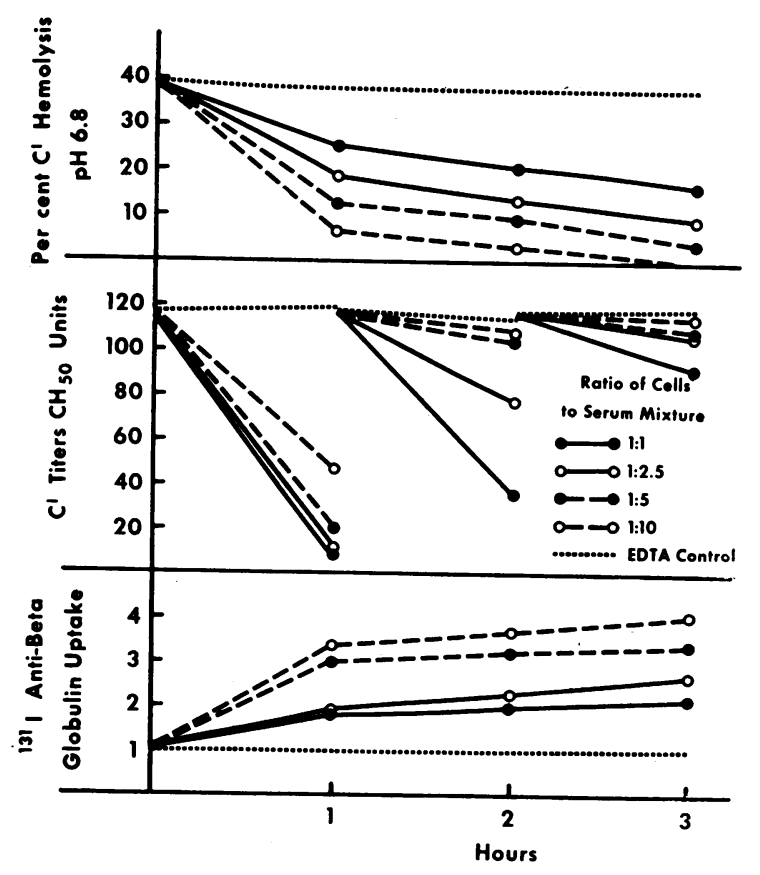

Fig. 4. ThE EFFECT OF INCREASING THE RATIO OF A MIXTURE OF COLD AGGLUTININ AND NORMAL SERUM TO NORMAL RED CELLS UPON THE DEVELOPMENT OF RESISTANCE to $C^{\prime}$ hemolysis By Cold AGGLutinin. Middle frame shows the consumption of $C^{\prime}$ during each hour of incubation; bottom frame indicates the adsorption of anti- $\beta$ globulin activity. A suspension with EDTA added to block the action of $\mathrm{C}^{\prime}$ served as a control.

flected in the agglutination of the cells in dilutions of anti- $\beta$-globulin serum (Table IV).

The hemolysis of the cells during the $3 \mathrm{hr}$ of incubation with the serum of A.J. was less than $1 \%$ at the constant temperature and approximately $7 \%$ when the temperature was alternated between $31^{\circ}$ and $37^{\circ} \mathrm{C}$. The serum of E.M. produced $15 \%$ hemolysis at both temperatures.

Development by normal red cells of resistance to $C^{\prime}$ hemolysis by cold agglutinin during incubation in varying ratios of cold agglutinin and normal serum. Normal red cells were suspended in 1, $2.5,5$, and 10 volumes of a mixture of one part serum of E.M. and four parts normal serum at $\mathrm{pH}$ 7.2. The uptake of ${ }^{131} \mathrm{I}$-labeled anti- $\beta$-globulin serum and resistance to $C^{\prime}$ hemolysis by cold agglutinins was determined at the end of each hour. The $C^{\prime}$ level of each of the serum mixtures used for incubation was compared with the preincubation level and with the level of the control sample of EDTA serum. The results of these determina- tions are presented in Fig. 4. The hemoglobin appearing in each supernatant serum sample during the hour of incubation was determined relative to $100 \%$ hemolysis (Table V).

The adsorption of ${ }^{131}$ I-labeled anti- $\beta$-globulin serum, the agglutination in dilutions of anti- $\beta$ globulin serum, and the development of resistance to $C^{\prime}$ hemolysis were directly related to the volume of serum mixture to which the red cells were exposed. Larger volumes of serum produced greater hemolysis during the $1 \mathrm{st} \mathrm{hr}$ of incubation but less hemolysis during the 2 nd and $3 \mathrm{rd} h \mathrm{hr} . \mathrm{C}^{\prime}$ assays indicated that more complete adsorption of $\mathrm{C}^{\prime}$ occurred from the smaller volumes of incubation medium though the total amount adsorbed on the cells as measured by adsorption of anti- $\beta$-globulin serum was less.

Effect of adsorbed $C^{\prime}$ globulins on the reaction with $C^{\prime}$. Incubation of red cells with cold agglutinins and $\mathrm{R} 3$ serum produced a progressive decrease in the uptake of ${ }^{131} \mathrm{I}$-labeled cold agglutinin. Experiments were designed to test whether inhibition of recombination with cold agglutinin accounted for all of the resistance to $\mathrm{C}^{\prime}$ hemolysis or whether inhibition of $\mathrm{C}^{\prime}$ action by $\mathrm{C}^{\prime}$ complexes previously adsorbed by the cells might also be a factor. Cells were coated with $\mathrm{C}^{\prime}$ globulin using R3 and cold agglutinin. Control cells were prepared in the same manner using EDTA in the serum to prevent $C^{\prime}$ coating. To observe the effect of concentration of cold agglutinin on $C^{\prime}$ hemolysis, we incubated both sets of cells at $25^{\circ} \mathrm{C}$, $\mathrm{pH} 6.8$, for $1 \mathrm{hr}$ in dilutions of radioiodinated cold agglutinin plus a constant amount of human $C^{\prime}$. Samples of the same suspensions were incubated with dilutions of the ${ }^{131}$ I-labeled cold agglutinin, plus a constant amount of EDTA-treated

TABLE V

$C^{\prime}$ hemolysis during incubation of I-positive cells with increasing volumes of E.M. serum and normal serum*

\begin{tabular}{ccccc}
\hline & \multicolumn{4}{c}{$\begin{array}{c}\text { Per cent hemolysis in a volume ratio of } \\
\text { cells to serum of : }\end{array}$} \\
\cline { 2 - 5 } Time & $1: 1$ & $1: 2.5$ & $1: 5$ & $1: 10$ \\
\hline$h r$ & & & & \\
1 & 1.7 & 5.4 & 7.4 & 16.9 \\
2 & 2.1 & 2.3 & 0.8 & 1.5 \\
3 & 2.4 & 1.7 & 0 & 0 \\
\hline
\end{tabular}

* The $\mathrm{pH}$ was adjusted to 7.2 and the incubation temperature alternated between $25^{\circ}$ and $37^{\circ} \mathrm{C}$. 


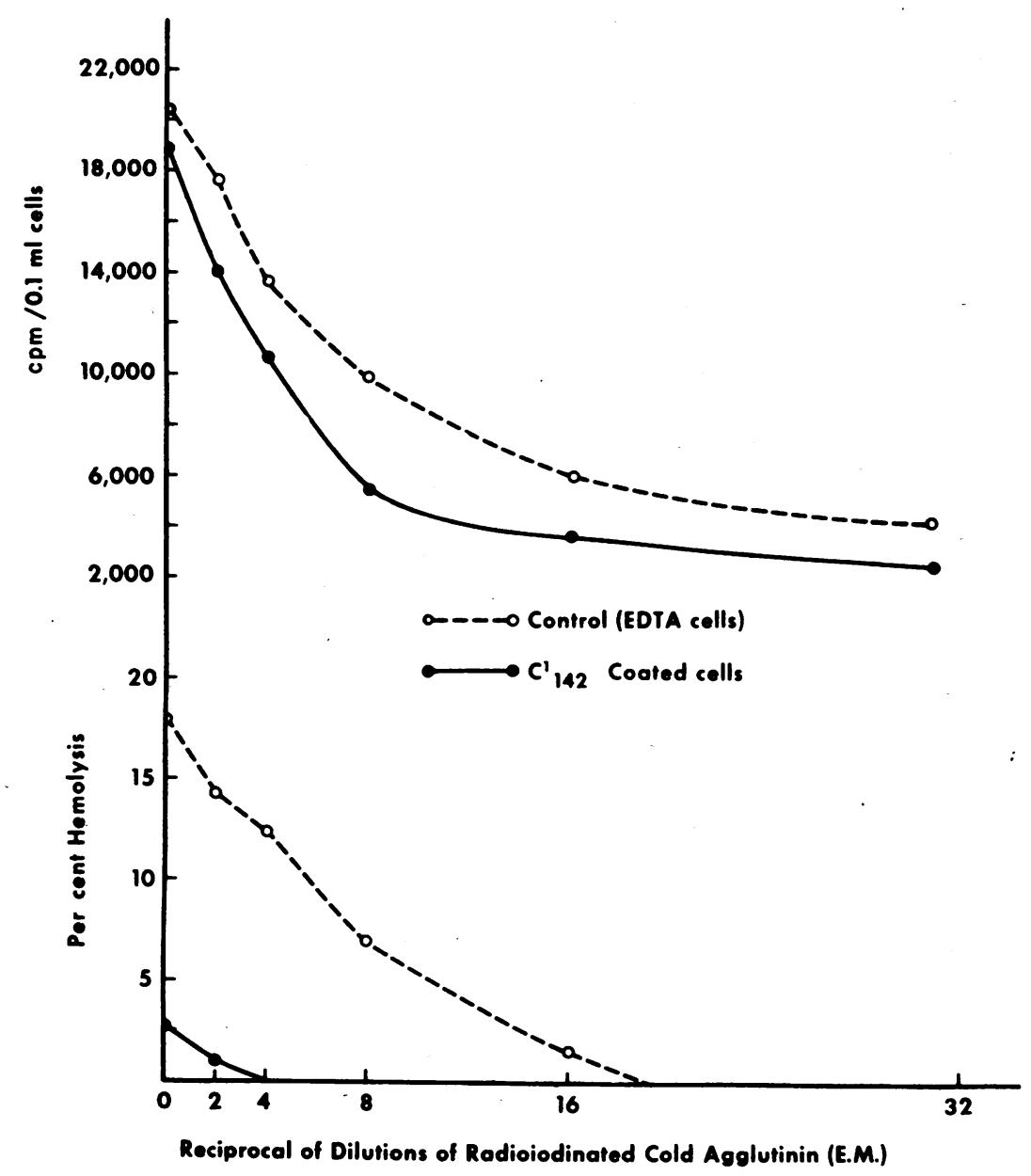

Fig. 5. Adsorption of ${ }^{131}$ I-LABEled cold agglutinin at $25^{\circ} \mathrm{C}$ By $\mathrm{C}^{\prime} 142$ cells AND BY CONTROL CELLS DURING INCUBATION IN DILUTIONS OF ${ }^{191}$ I-LABELED COLD AGGLUTININ (UPPER SCALE) AND THE PER CENT OF $C^{\prime}$ HEMOLYSIS OF SAMPLES OF THESE CELLS BY THE SAME CONCENTRATIONS OF THE ${ }^{181}$ I-LABELED COLD AGGLUTININ (LOWER SCALE). Reactions were carried out at pH. 6.8 .

serum, to measure the uptake of ${ }^{131} \mathrm{I}$ cold agglutinin activity in the absence of hemolysis (Fig. 5).

For purposes of calculation, we assumed the radioactivity of the red cells after washing three times at $25^{\circ} \mathrm{C}$ to reflect the amount of cold agglutinin adsorbed to the cell, although we recognize some was eluted during washing. From the ${ }^{131}$ I activity of the original preparation of tagged protein using $1.0 \times 10^{8}$ as the molecular weight of the antibody, we calculated that 40,000 molecules of cold agglutinin per cell were present when $2.5 \%$ hemolysis of the control cells occurred, whereas 112,000 molecules were present when $2.5 \%$ hemolysis of the cells previously coated with $\mathrm{C}^{\prime}$ globulin occurred (2). These data indi- cate that several times the concentration of cold agglutinin must be adsorbed to the surface of red cells coated with $\mathrm{C}^{\prime}$ globulins compared to uncoated cells to produce equal hemolysis. This finding suggests that the adsorbed $C^{\prime}$ globulins inhibited $C^{\prime}$ action as well as the reaction with cold agglutinin.

I antigen content of red cells of patients with hemolytic disease due to cold agglutinins. As shown in the above experiments, resistance to $C^{\prime}$ hemolysis by cold agglutinin can be acquired by normal cells through accumulation of $C^{\prime}$ globulin. An alternative explanation for the resistance of patients' red cells to $C^{\prime}$ hemolysis by cold agglutinins might be lack of I antigen. Preparations of 
TABLE VI

Susceptibility of group 0 I-positive red cells to $C^{\prime}$ hemolysis after separation by agglutination in decreasing cold agglutinin concentrations*

\begin{tabular}{lccc}
\hline \hline & \multicolumn{2}{c}{ Per cent of original cells } & \\
\cline { 2 - 3 } $\begin{array}{c}\text { Dilutions of } \\
\text { E.M. serum }\end{array}$ & $\begin{array}{c}\text { Unagglu- } \\
\text { tinated }\end{array}$ & $\begin{array}{c}\text { Agglu- } \\
\text { tinated }\end{array}$ & $\begin{array}{c}\text { Per cent } \\
\text { hemolysis }\end{array}$ \\
\hline $1: 20$ & 3 & - & 9 \\
$1: 80$ & 14 & - & 17 \\
$1: 320$ & 32 & - & 26 \\
$1: 1280$ & 38 & - & 38 \\
$1: 5120$ & 11 & - & 43 \\
$1: 5120$ & - & 2 & 43 \\
$1: 1280$ & - & 19 & 42 \\
$1: 320$ & - & 55 & 42 \\
$1: 80$ & - & 11 & 29 \\
$1: 20$ & - & 2 & 21 \\
$1: 20$ & 11 & - & 17 \\
\hline
\end{tabular}

* An aliquot of the same population was separated by susceptibility to agglutination in increasing concentration of cold agglutinin.

stroma from normal adult and cord red cells have been found to reflect the I content of the cells (2). Stroma prepared from measured quantities of whole cells of E.M. and A.J. were found to adsorb as much ${ }^{131}$ I-labeled cold agglutinin as similar preparations of normal adult I-positive cells.

Heterogeneity of normal red cells in susceptibility to agglutination and $C^{\prime}$ hemolysis by cold agglutinin. The resistance of the circulating cells of the patients to $\mathrm{C}^{\prime}$ hemolysis by cold agglutinins might be due in part to heterogeneity of the red cells of the patient to reaction with cold agglutinins and survival of the most resistant population. To test this hypothesis, we separated I-positive cells of normal individuals into fractions on the basis of their susceptibility to agglutination in increasing or in decreasing concentrations of cold agglutinin. Cells from each population were tested for susceptibility to $\mathrm{C}^{\prime}$ hemolysis by cold agglutinin. The results of one of several experiments from normal I-positive donors are shown in Table VI.

It is evident that red cells of a normal I-positive subject can be separated by susceptibility to agglutination in both increasing and decreasing concentrations of cold agglutinins into populations that show some variation in susceptibility to $\mathrm{C}^{\prime}$ hemolysis by cold agglutinin. In both methods of separation, the red cells that showed least susceptibility to agglutination were least susceptible to $\mathrm{C}^{\prime}$ hemolysis. A small percentage $(0.5-2.0 \%)$ of red cells of normal subjects was found to be completely resistant to both agglutination and $\mathrm{C}^{\prime}$ hemolysis by cold agglutinin. Such cells agglutinated very weakly in anti- $\beta$-globulin serum after $1 \mathrm{hr}$ of incubation with cold agglutinin and normal serum, indicating a decreased ability to acquire a coating of $\beta_{1 \mathrm{e}^{-}}$and $\beta_{1 \mathrm{c}^{-}}$-globulins. Reticulocytes were not more numerous in the small population of resistant cells.

Resistance of reticulocytes to $C^{\prime}$ hemolysis. Susceptibility of red cells to $C^{\prime}$ hemolysis may be influenced by changes brought about by cell age. Red cells produced by the bone marrow under stress have been shown to have increased reactivity with cold agglutinins of anti-i specificity, although there is no evidence of an accompanying decrease in I factor (21). Young red cells produced in experimental hemolytic anemia have been found to be more resistant to heterospecific antibody than normal red cells (22). $\mathrm{C}^{\prime}$ hemolysis of populations with increased reticulocytes was investigated to determine if young red cells were more or less susceptible to $C^{\prime}$ hemolysis by cold agglutinins than mature cells. Reticulocyte counts were performed by the same technique before and after the production of partial hemolysis by normal serum and cold agglutinin at $\mathrm{pH} 6.8$ and $25^{\circ} \mathrm{C}$

TABLE VII

Susceptibility to $C^{\prime}$ hemolysis by cold agglutinin after separating red cells of two patients with posthemorrhagic reticulocytosis into a reticulocyte-rich and a reticulocyte-pocr layer

\begin{tabular}{|c|c|c|c|c|}
\hline Patient & Test & $\begin{array}{l}\text { Whole blood } \\
\text { cells }\end{array}$ & $\begin{array}{l}\text { Retic.-rich } \\
\text { cells }\end{array}$ & $\begin{array}{l}\text { Retic.-poor } \\
\text { cells }\end{array}$ \\
\hline M.C. & $\begin{array}{l}\mathrm{C}^{\prime} \text { hemolysis with cold agglutinin } \\
\text { Reticulocytes before } \mathrm{C}^{\prime} \text { hemolysis, } \% \\
\text { Reticulocytes after } \mathrm{C}^{\prime} \text { hemolysis, } \%\end{array}$ & $\begin{array}{r}29 \\
4.2 \\
3.7\end{array}$ & $\begin{array}{r}30 \\
8.8 \\
8.6\end{array}$ & $\begin{array}{r}30 \\
2.0 \\
2.4\end{array}$ \\
\hline F.J. & $\begin{array}{l}\mathrm{C}^{\prime} \text { hemolysis with cold agglutinin } \\
\text { Reticulocytes before } \mathrm{C}^{\prime} \text { hemolysis, } \% \\
\text { Reticulocytes after } \mathrm{C}^{\prime} \text { hemolysis, } \%\end{array}$ & $\begin{array}{r}45 \\
7.9 \\
8.2\end{array}$ & $\begin{array}{l}42 \\
32.7 \\
32.4\end{array}$ & $\begin{array}{r}42 \\
4.2 \\
3.9\end{array}$ \\
\hline
\end{tabular}


and after incubation of samples of the same cells with cold aglutinin and heat-inactivated normal serum.

In two of 15 patients having increased blood formation and a variety of hematologic disorders, reticulocytes were somewhat more resistant to $\mathrm{C}^{\prime}$ hemolysis than normal cells. Reticulocyte counts increased from 8 to $11 \%$ after $51 \%$ hemolysis of the whole cells of one patient with uremia and from 6 to $10 \%$ after $50 \%$ hemolysis of the red cells of a patient with chronic myelogenous leukemia. Reticulocyte counts of other patients remained unchanged after hemolysis by cold agglutinins.

The susceptibility of reticulocytes to $C^{\prime}$ hemolysis by cold agglutinins was also determined after separating whole blood from patients with a posthemorragic reticulocytosis into a reticulocyterich layer and a reticulocyte-poor layer by differential centrifugation (Table VII). Varying the number of reticulocytes did not significantly influence the susceptibility of the red cells to $C^{\prime}$ hemolysis by cold agglutinin.

Resistance of cells coated with $C^{\prime}$ globulins by action of cold agglutinin to $C^{\prime}$ hemolysis by anti- $A$. Normal group A, I-positive cells were made resistant to $C^{\prime}$ hemolysis by anti-I cold agglutinin and $C^{\prime}$. Control suspensions were prepared by the addition of EDTA to the incubation medium to block the action of $C^{\prime}$. Suspensions of the resistant and control cells were then tested for susceptibility to $\mathrm{C}^{\prime}$ hemolysis in 20 volumes of anti-A human serum.

Such $C^{\prime}$-coated cells exhibited slight resistance to $\mathrm{C}^{\prime}$ hemolysis by anti-A as shown in Table VIII. In 10 other experiments, the $C^{\prime} 1423$ cells were 2-30\% more resistant to $\mathrm{C}^{\prime}$ hemolysis by anti-A than were the normal cells. At the same time, these cells were $60-77 \%$ more resistant to $\mathrm{C}^{\prime}$ hemolysis by cold agglutinin.

Effect of coating normal red cells with incomplete anti-D antibody on susceptibility to $C^{\prime}$ hemolysis by cold agglutinin. Normal group O, R1 R2 I-positive cells were incubated with 10 volumes of incomplete anti-D antibody with a titer of $1: 1000$. The washed cells were shown to be agglutinated by antiglobulin serum and were presumed from previous experience with this serum to have nearly maximal coating of anti-D antibody (23). These anti-D coated cells were found
TABLE VIII

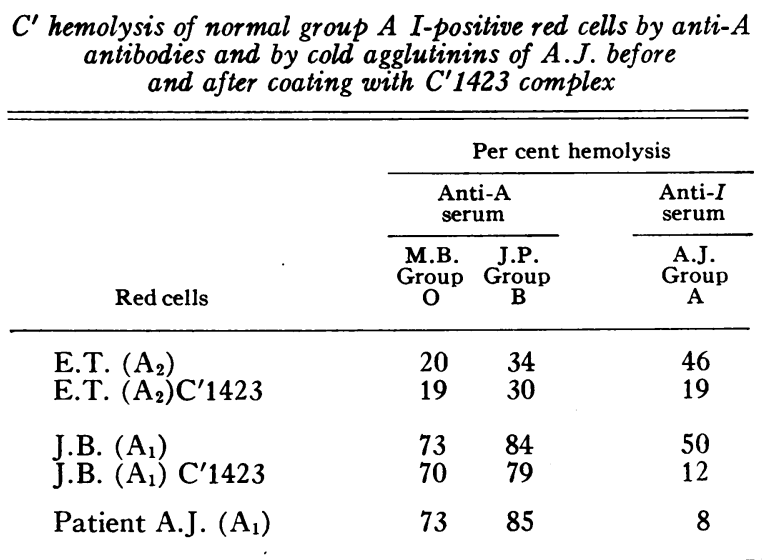

The susceptibility to hemolysis was determined by incubation of the cells in 20 volumes of serum for $1 \mathrm{hr}$ at $25^{\circ} \mathrm{C}, \mathrm{pH} 6.8$. Normal serum was mixed with serum of A.J. to provide human $\mathrm{C}^{\prime}$.

to be as susceptible to $\mathrm{C}^{\prime}$ hemolysis by cold agglutinins as samples of the same suspension before coating with anti-D antibody. Cells coated with anti-D antibody also adsorbed as much radioiodinated cold agglutinin as normal cells.

\section{Discussion}

The reaction between cold agglutinins and red cells is only transient at normal body temperature. Above $31^{\circ} \mathrm{C}$ most cold agglutinins do not produce agglutination and are sufficiently dissociated to be completely removed from the cell suspension by repeated washings at $37^{\circ} \mathrm{C}$. Despite this, there is evidence of transient reaction between cold agglutinins and the red cell surface at $37^{\circ} \mathrm{C}$, since the cold agglutinins of some patients are capable of producing partial $\mathrm{C}^{\prime}$ hemolysis at $37^{\circ} \mathrm{C}$. The red cells which do not undergo hemolysis are coated with C'1423 complex. The cold agglutinins of other patients deposit $\mathrm{C}^{\prime} 1423$ complex at $37^{\circ} \mathrm{C}$ without producing hemolysis.

Evidence is lacking that the fixation of $\mathrm{C}^{\prime}$ binds the cold agglutinin to the red cell and interferes with dissociation at body temperature. Since cold agglutinin dissociates readily, it probably reacts repeatedly with the same or other antigen sites and fixes $C^{\prime} 1423$ complex with each reaction. Accumulation of $C^{\prime}$ complexes on the red cell surface with time decreases the reactivity of the red cell with both cold agglutinin and $\mathrm{C}^{\prime}$ globulins. 
The adsorption of ${ }^{131} \mathrm{I}$ activity from anti- $\beta$-globulin serum and the agglutination in dilutions of the same antisera provide the best methods available for demonstrating the accumulation of $\mathrm{C}^{\prime}$ globulins. The anti- $\beta$-globulin serum used in this study had not been purified by adsorption and elution from its antigen because of difficulties in obtaining pure $\beta_{1 c^{-}}$and $\beta_{1 e^{-}}$globulin. Consequently, the radioiodinated antisera had a relatively high nonspecific activity due to the adherence of radioiodinated globulin or lipoprotein to the red cells in nonimmune reaction (24). It has been demonstrated repeatedly that the nonspecific adsorption of such protein does not result in a positive agglutination test with any antiglobulin antibody (23, $25)$. The red cells of normal subjects do not vary significantly in the adsorption of the labeled nonantibody protein. There is evidence that adsorption of radioactivity above the base line for normal red cells in the experiments described above was due to the anti- $\beta_{1 c^{-}}$and anti- $\beta_{1 e^{-}}$-antibodies. Only red cells known to have adsorbed $C^{\prime}$ globulins were agglutinated by the antisera or adsorbed radioactivity above the base line. The adsorption of ${ }^{131}$ I-labeled anti- $\beta$-globulin was directly related to the time of incubation with cold agglutinin and $\mathrm{C}^{\prime}$ and to the amount of $\mathrm{C}^{\prime}$ provided by the incubation medium. Concomitantly, the degree of agglutination of the incubated cells in dilutions of

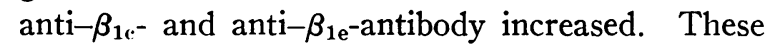
observations suggest that the reaction between anti- $\beta_{1 c^{-}}$and anti- $\beta_{1 e^{-a n t i b o d i e s ~ a n d ~ t h e i r ~ r e-~}}$ spective antigens will prove to be stoichiometric, as has been shown to be true of anti- $\gamma \mathrm{G}$ and incomplete $\gamma \mathrm{G}$ antibodies adsorbed to red cells $(26,27)$.

The development of resistance to $\mathrm{C}^{\prime}$ hemolysis by cold agglutinin which followed prolonged incubation of normal red cells with cold agglutinins and R3 serum or with cold agglutinins and whole serum is presumed to be due to steric hindrance by the accumulated $\mathrm{C}^{\prime}$ globulins. Resistance to hemolysis was directly related to the quantity of $C^{\prime}$ globulin complex adherent to the cell, as measured by radioiodinated anti- $\beta$-globulin serum. Adsorption of ${ }^{131}$ I-labeled cold agglutinin was reduced as $\mathrm{C}^{\prime}$ globulins accumulated. In addition, there was evidence that $C^{\prime}$-coated red cells must adsorb more cold agglutinin than normal red cells to undergo similar degrees of hemolysis. This suggests that the residual $\mathrm{C}^{\prime}$ complex also inter- fered with reinitiation of $\mathrm{C}^{\prime}$ hemolysis even though antibody attachment had occurred.

Some degree of specificity of the steric hindrance produced by deposition of $\mathrm{C}^{\prime}$ complexes is suggested by the failure of anti-D antibody coating of red cells to inhibit either $C^{\prime}$ hemolysis or the reattachment of ${ }^{131} \mathrm{I}$-labeled cold agglutinin. It must be added that the concentration of globulin in the two systems was probably not comparable, since it has been computed that there are approximately 500,000 antigen sites for the cold agglutinin and less than one-tenth that number for anti-D antibody $(2,27)$. Probably many more molecules of $\mathrm{C}^{\prime}$ globulin can be attached to red cells by cold agglutinin than the number of $\gamma \mathrm{G}$ molecules represented by maximum concentration of $\mathrm{D}$ antibody. Furthermore, some fractions of $\mathrm{C}^{\prime}$ are macromolecular and may be more effective in producing steric hindrance than the anti-D antibody. The $\mathrm{C}^{\prime}$ globulins deposited on the red cell surface by the cold agglutinin inhibited hemolysis of red cells by anti-A antibody to a lesser degree than the inhibition of $C^{\prime}$ hemolysis by cold agglutinin. This suggests the possibility of proximity of A and I antigen sites, as proposed by previous work (28).

The composition of the $\mathrm{C}^{\prime}$ globulins remaining adherent to the red cells after incubation with cold agglutinin and R3 is uncertain. The R3 serum produced by reacting whole serum with zymosan at $37^{\circ} \mathrm{C}$ was devoid of hemolytic activity due to the inactivation of some of the fractions of $C^{\prime} 3$, including the conversion of some but not all $\beta_{1 \mathrm{c}^{-}}$to $\beta_{1 \mathrm{a}}$-globulin (14). Red cells incubated with cold agglutinin and R3 serum were agglutinated in antiserum believed to contain only anti- $\beta_{1 e^{-a n t i-}}$ bodies and to a lesser degree in antisera with only anti- $\beta_{1 \mathrm{c}}$-antibodies. The amount of $\beta_{1 \mathrm{c}}$-globulin present and the extent to which it and other fractions of the third component of $\mathrm{C}^{\prime}$ stabilized the $\mathrm{C}^{\prime} 142$ complex on the red cells is not known (15). Incubation of the $\mathrm{C}^{\prime}$-coated cells at $37^{\circ} \mathrm{C}$ for $1 \mathrm{hr}$ to prepare EC14 cells did not result in return of susceptibility to $\mathrm{C}^{\prime}$ hemolysis by cold agglutinin. Similarly, incubation with EDTA for $3 \mathrm{hrs}$ at $0^{\circ} \mathrm{C}$ to elute $\mathrm{C}^{\prime} 1 \mathrm{a}$ did not affect the resistance to hemolysis (29).

The red cells of normal subjects vary considerably in susceptibility to agglutination and to $C^{\prime}$ hemolysis by cold agglutinins of anti-I specificity $(30,31)$. Moreover, the red cell population of a 
single individual showed significant heterogeneity with regard to susceptibility to agglutination. Resistance to agglutination was reflected in greater resistance to $C^{\prime}$ hemolysis. How much the heterogeneity of the red cells of one individual contributes to the resistance of the red cells of patients to complement hemolysis by cold agglutinin is uncertain at present. Red cells of the patient which are most resistant to the action of cold agglutinin probably do survive better in the circulation but it is unlikely that survival of such cells accounts for more than a fraction of the observed resistance to $C^{\prime}$ hemolysis. The small percentage of red cells of normal individuals which are resistant to $C^{\prime}$ hemolysis are also resistant to $C^{\prime}$ coating by action of cold agglutinin. In contrast, the patients' cells which are resistant to $C^{\prime}$ hemolysis are coated with $\mathrm{C}^{\prime}$ globulin complexes, as shown by the high uptake of ${ }^{131} \mathrm{I}$-labeled anti- $\beta$-globulin serum and by intense agglutination in anti- $\beta$-globulin serum. Reticulocytes of a minority of patients with increased blood formation were somewhat resistant to $C^{\prime}$ hemolysis when compared to red cells beyond the reticulocyte stage. The contribution of the young red cells in cold agglutinin hemolytic anemia to the resistance of the circulating cells of the patient to $\mathrm{C}^{\prime}$ hemolysis by cold agglutinin appears to be a minor factor.

Others have noted the inhibition of antigen antibody reactions by adsorption of $\mathrm{C}^{\prime}$ globulins to red cells. Laurell observed that sheep cells which had adsorbed $\mathrm{C}^{\prime}$ complex from the action of human $\mathrm{R} 3$ and rabbit anti-sheep cell antibody were more resistant to agglutination by rheumatoid factor than control cells which had not adsorbed $\mathrm{C}^{\prime}$ complex (32). Möller has studied the resistance of mouse cells to $\mathrm{C}^{\prime}$ hemolysis by isoantibodies which developed through prior exposure of the cells to the antibody and normal serum factors presumed to be $C^{\prime}(33)$. The development of resistance to antibody action may occur in a variety of systems in which fixation of $\mathrm{C}^{\prime}$ fractions is followed by dissociation of the antibody.

It is probable that $\mathrm{C}^{\prime}$ globulins accumulate on the red cells in vivo as the result of mechanisms similar to those used in the in vitro studies. Alterations in temperature of the blood flowing from skin vessels to viscera was postulated to be a factor in the adsorption and release of cold agglutinin by the red cells. In vitro experiments in which the temperature was kept constant at $33^{\circ} \mathrm{C}$ as shown in Fig. 3 or at $31^{\circ}$ or $37^{\circ} \mathrm{C}$ in other experiments resulted in a somewhat slower accumulation of $\mathrm{C}^{\prime}$ globulins, compared with those in which the temperature was alternated between $31^{\circ}$ and $37^{\circ} \mathrm{C}$. These observations suggest that the normal variations of temperature of the circulation between viscera and surface vessels were not essential for the association and dissociation of the cold agglutinin in vivo and the consequent accumulation of $\mathrm{C}^{\prime}$ globulins on the red cell surface. Although the development of resistance to $\mathrm{C}^{\prime}$ hemolysis by accumulation of $C^{\prime}$ globulin was accompanied by a decreased susceptibility to agglutination by dilutions of cold agglutinins, this did not prevent the development of acrocyanosis due to intravascular agglutination when the temperature of the skin was sufficiently reduced.

\section{References}

1. Dacie, J. V., J. H. Crookston, and W. N. Christenson. 1957. "Incomplete" cold antibodies: role of complement in sensitization to antiglobulin serum by potentially hemolytic antibodies. Brit. J. Haematol. $3: 77$.

2. Evans, R. S., E. Turner, and M. Bingham. 1965. Studies with radioiodinated cold agglutinins of ten patients. Am. J. Med. $38: 378$.

3. Evans, R. S., E. Turner, and M. Bingham. 1964. Studies with I-131 tagged cold agglutinins. Proceedings of the 9th Congress of the International Society for Blood Transfusion, Mexico, 1962. 347.

4. Harboe, M. 1964. Interaction between ${ }^{131} \mathrm{I}$ tracelabelled cold agglutinin, complement and red cells. Brit. J. Haematol. 10: 339.

5. Evans, R. S., E. Turner, and M. Bingham. 1965. The resistance of $\mathrm{C}^{\prime}{ }_{142}$ coated cells to complement hemolysis by cold agglutinins. Proceedings of the 10th Congress of the International Society of Blood Transfusion, Stockholm, 1964. 834.

6. Gold, E. R., W. J. Lockyer, and G. H. Tovey. 1958. Use of lyophilized formol-treated red cells in blood-group serology. Nature. 182 : 951.

7. Müller-Eberhard; H. J., U. Nilsson, and T. Aronsson. 1960. Isolation and characterization of two $\beta_{1}$ glycoproteins of human serum. J. Exptl. Med. 111: 201.

8. Müller-Eberhard, H. J., and C. E. Biro. 1963. Isolation and description of the fourth component of human complement. J. Exptl. Med. 118: 447.

9. Kabat, E. A., and M. M. Mayer. 1961. Experimental Immunochemistry. Charles C Thomas, Publisher, Springfield. 2nd edition. 162.

10. Austen, K. F., and F. Beer. 1964. The measurement of second component of human complement $\left(\mathrm{C}^{\prime}\right.$ 
$\left.2^{\text {hu }}\right)$ by its interaction with EAC' 1a g.p. 4 g.p. cells. J. Immunol. 92 : 946.

11. Horejsi, J., and R. Smetana. 1956. The isolation of gamma globulin from blood-serum by rivanol. Acta Med. Scand. 155: 65.

12. Helmkamp, R. W., R. L. Goodland, W. F. Bale, I. L. Spar, and L. E. Mutschler. 1960. High specific activity iodination of gamma globulin with iodine-131 monochloride. Cancer Res. 20: 1495.

13. Costea, N., R. Schwartz, M. Constantoulakis, and W. Dameshek. 1962. The use of radioactive antiglobulin for detection of erythrocyte sensitization. Blood. 20: 214.

14. Pondman, K. W., and F. Peetoom. 1964. The significance of antigen-antibody complement reaction. IV. The transformation of $\beta_{1 \mathrm{c}}$-globulin into $\beta_{1 \mathrm{a}}$ globulin. Immunochemistry. I : 65.

15. Nilsson, U. R., and H. J. Müller-Eberhard. 1965. Isolation of $\beta_{11}$ globulin from human serum and its characterization as the fifth component of complement. J. Exptl. Med. 122: 277.

16. Ecker, E. E., L. Pillemer, and S. Seifter. 1943. Immunochemical studies on human serum. Human complement and its components. J. Immunol. 47 : 181.

17. Pillemer, L., L. Blum, I. H. Lepow, L. Wurz, and E. W. Todd. 1956. The properdin system and immunity. III. The zymosan assay of properdin. J. Exptl. Med. 103: 1.

18. Kan, S. Y., and F. H. Gardner. 1965. Life span of reticulocytes in paroxysmal nocturnal hemoglobinuria. Blood. 25: 759.

19. Nelson, R. A. 1958. An alternative mechanism for the properdin system. J. Exptl. Med. 108: 515.

20. Marsh, W. L. 1961. Anti i: A cold antibody defining the Ii relationship in human red cells. Brit. J. Haematol. $7: 200$.

21. Hillman, R. S., and E. R. Giblett. 1965. Red cell membrane alteration associated with "marrow stress." J. Clin. Invest. 44 : 1730.

22. Gower, D. B., and W. M. Davidson. 1963. The mechanism of immune hemolysis. I. The relationship of the rate of destruction of red cells to their age, following the administration to rabbits of an immune haemolysin. Brit. J. Haematol. 9: 132.
23. Evans, R. S., E. Turner, and M. Bingham. 1963. Studies of $\mathrm{I}^{131}$ tagged $\mathrm{Rh}$ antibody of $\mathrm{D}$ specificity. Vox Sanguinis. 8: 153.

24. Hughes-Jones, N. C., and B. Gardner. 1962. The exchange of ${ }^{131} \mathrm{I}$-labelled lipid and ${ }^{181} \mathrm{I}$-labelled protein between red cells and serum. Biochem. J. 83 : 404.

25. Pirofsky, B., M. S. Cordova, and T. L. Imel. 1962. The nonimmunologic reaction of globulin molecules with the erythrocyte surface. Vox Sanguinis. $7: 334$.

26. Constantoulakis, M., N. Costea, R. S. Schwartz, and W. Dameshek. 1963. Quantitative studies of the effect of red blood cell sensitization on in vivo hemolysis. J. Clin. Invest. 42: 1790.

27. Rochna, E., and N. C. Hughes-Jones. 1965. The use of purified ${ }^{125}$ I-labelled anti $\gamma$ globulin in the determination of the number of $\mathrm{D}$ antigen sites on red cells of different phenotypes. Vox Sanguinis. 10: 675 .

28. Marcus, D. M., E. A. Kabat, and R. E. Rosenfield. 1963. The action of enzymes from Clostridium tertium on the I antigenic determinant of human erythrocytes. J. Exptl. Med. 118: 175.

29. Becker, E. L., 1960 . Concerning the mechanism of complement action. V. The early steps in immune hemolysis. J. Immunol. 84 : 299.

30. Crookston, J. H., J. V. Dacie, and V. Rossi. 1956. Difference in agglutinability of human red cells by the high-titre cold antibodies of acquired haemolytic anemia. Brit. J. Haematol. 2: 321.

31. Lewis, S. M., J. V. Dacie, and D. Tills. 1961. Comparison of the sensitivity to agglutination and haemolysis of high-titre cold antibody of the erythrocytes of normal subjects and of patients with a variety of blood diseases, including paroxysmal nocturnal haemoglobinuria. Brit. J. Haematol. $7: 64$.

32. Laurell, A. 1963. Comparison of agglutinability by rheumatoid arthritic sera of sensitized sheep cells and of sensitized sheep cells exposed to $\mathrm{C}^{\prime}{ }_{1}$ $\mathrm{C}_{4}^{\prime}$ and $\mathrm{C}_{2 .}^{\prime}$ Acta Pathol. Microbiol. Scand. 59: 73.

33. Möller, G. 1964. Iso-antibody-induced cellular resistance to immune haemolysis in vivo and in vitro. Nature. 202: 357. 